Academic
$\begin{aligned} & \text { Journal of } \\ & \text { Islamic Studies }\end{aligned}$ $\begin{array}{r}\text { Institut Agama Islam Negeri (IAIN) Curup, Indonesia } \\ \text { ISSN 2580-3174, (p); 2580-3190 (e) } \\ \text { volume 6, number 2, 2021 | page: 147-180 } \\ \text { DOI: http://doi.org/10.29240/ajis.v6i2.3325 }\end{array}$

\title{
The Genealogy of Ali Mustafa Yaqub's Hadith Understanding
}

\author{
Fatihunnada, Hasan Basri Salim \\ UIN Syarif Hidayatullah Jakarta, Indoneisa \\ fatihunnada@uinjkt.ac.id,hasan.basri@uinjkt.ac.id
}

\begin{abstract}
Ali Mustafa is an Indonesian hadith expert who has had a significant influence on the development of hadith studies in Indonesia in term of the study of hadith authenticity and the study of hadith understanding. This article explores Ali Mustafa's genealogy of understanding, method of understanding, and academic experiences during his education in Indonesia and Saudi Arabia. The data sources for this paper were Ali Mustafa's work entitled Female Imam, The Meeting Point of Wahabi-NU, and Islam is not only for Muslims. Through text analysis method with a genealogical approach, it can be described that Ali Mustafa's understanding of Genealogy was strongly influenced by several sources such as NU, Wahabi, Occidentalism, and the understanding of classical scholars. Ali Mustafa understood the hadith with the textual method first, then he used contextual method if the textual method could not be used to understand the hadith. The influence of Ali Mustafa's education in Indonesia through Islamic boarding schools was stronger than his educational experience in Saudi Arabia.
\end{abstract}

Keywords: Ali Mustafa; Genealogy; Hadith Understanding

\section{Introduction}

Several Indonesian hadith experts try to reconstruct the understanding of hadith with a different style from the other hadith experts. The main factor behind the birth of this reconstruction effort is the current development that encourages the development of science due to the increasingly complicated problems that arise today. The reconstruction of hadith understanding occurs in the study of understanding hadith. Some classical methods of understanding hadith are considered inappropriate in answering contemporary problems. ${ }^{1}$ The

\footnotetext{
1Patrick Sookhedeo, "Issues of Interpreting the Koran and Hadith," The Quarterly Journal 5, no. 3 (2006): 57-83, https://doi.org/http://dx.doi.org/10.11610/Connections.05.3.06. Yūsuf Al-Qaraḍāwī, Al-Khașāiș Al-'Āmmah Li Al-Islām (Beirut: Mu'assasah ar-Risālah, 1977), 178-212. Muștafā As-Sibā'ī, As-Sunnah an-Nabawīyah Wa Makānatuhā Fī at-Tasyrī' Al-Islāmī
} 
birth of the hadith is the Prophet's response to the phenomena that occurred in the context of the life of the Prophet, so that the hadith is very connected to the context when it was spoken by the Prophet and when it was practiced by Muslims after the death of the Prophet. ${ }^{2}$

The geographical context and areas of practice of hadith which are very different from the context of the birth of hadith in Mecca and Medina, such as in Indonesia, also encourage hadith experts to adapt the understanding of hadith to local conditions. ${ }^{3}$ Geographic context is one of the approaches used by hadith experts such as Ali Mustafa ${ }^{4}$ as an effort to understand the hadith more precisely. If a hadith is forced to be understood based on the geographical context of Mecca and Medina as the birthplace of the hadith, then there will be problems in practicing it.

Several hadith experts who made efforts to reconstruct the method of understanding hadith are T.M. Hasbi ash Shiddieqy, Daud Rasyid Sitorus, Muhajirin Amsar, Ali Mustafa Yaqub, Said Agil al-Munawar, and Lutfi Fathullah who are Middle East alumni. On the other hand, Komarudin Amin is also included in this rank with a Western educational background. From within the country itself, there are several figures who can be classified as hadith experts. They are Muhammad Syhudi Ismail, Ahmad Surkati, and Ahmad Hasan. ${ }^{5}$

(Beirut: Dār al-Kutub al-'Ilmīyah, 2004), 72-74. Dan Daniel W. Brown, Rethinking Tradition Modern Islamic Thought Indeks (Cambridge: Cambridge University Press, 1999), 245.

2Muhammad Irfan Helmy, Kontekstualisasi Hadis: Telaah Atas Asbab Al-Wurud Dan Kontribusinya Terhadap Pemahaman Hadis (Yogyakarta: Mitra Cendekia, 2007), 58.

${ }^{3}$ Ali Mustafa Yaqub, Aț-Turuq Aș-Ṣahịhah Fī Fahm as-Sunnah Al-Nabawìyah (Jakarta: Maktabah Darus-Sunnah, 2016), 75. Dan Ali Mustafa Yaqub, Cara Benar Memahami Hadis (Jakarta: Pustaka Firdaus, 2016), 75.

${ }^{4}$ Fatihunnada and Afaf Nazrat Uyun Anis, "Pemahaman Hadis Doa Pengalihan Hujan Pendekatan Geografis Jakarta Menurut Ali Mustafa Yaqub," ILMU USHULUDDIN 7, no. 1 (2020): 37-56, https://doi.org/https://doi.org/10.15408/iu.v7i1.14698. Lihat juga: Yaqub, Aț-Ṭruq Aș-Sahīhah Fī Fahm as-Sunnah Al-Nabawīyah, 75.

${ }^{5}$ Hasep Saputra, “Genealogi Perkembangan Studi Hadis DI Indonesia," AL QUDS : Jurnal Studi Alquran Dan Hadis 1, no. 1 (2017): 41-68, https://doi.org/http://dx.doi.org/10.29240/alquds.v1i1.164. dan Hasep Saputra, "Perkembangan Studi Hadis Di Indonesia: Pemetaan Dan Analisis Ganeologi" (UIN Syarif Hidayatullah, 2014), 17-18. 
Reconstruction of the understanding of hadith aims to enable Indonesian people to accept the practice of the prophet's hadith. In the mid-twentieth century, Islamic religious figures in Indonesia had made a real contribution to reform. This was also done by Indonesian hadith experts, including Hasbi ash Shiddieqy. ${ }^{6} \mathrm{He}$ also contributed to renewal by contributing ideas in the form of understanding the Qur'an and hadith that cannot be separated from the conditions of Indonesian society. Therefore, the concept of Indonesian Fiqh was born. He views that Indonesian Jurisprudence cannot be separated from the root sources of Islamic teachings, namely the Qur'an and Hadith, but understanding of both cannot be separated from the Indonesian context. ${ }^{7}$ Hasbi ash Shiddieqy also contributed to reaffirming the difference between hadith and sunnah which has long been debated by hadith experts and fiqh experts. According to him, hadith is data related to the Prophet that has legal value in Islamic jurisprudence, while sunnah is prophetic data that has mutawatir value in substance transmission. ${ }^{8}$

This is different from Shuhudi Ismail who understands the sunnah as a behavior practiced by the Prophet and continues to be preserved by generations of companions and Tabin. Therefore, in understanding the hadith, three important stages are needed. First, doing a text analysis. Second, identifying the context of the hadith that emerges from the aspect of its social condition. Third, contextualizing the practice of hadith that is adapted to social conditions when the hadith will be practiced. ${ }^{9}$

Ali Mustafa has a contextual thought towards a very contextual understanding of hadith. This is proven by the method of understanding contextual hadith based on the geographical approach used for the

\footnotetext{
${ }^{6}$ Hasbi ash Shiddieqy yang lahir dari organisasi keagamaan PERSIS dengan ideologi "kembali kepada Al-Qur'an dan hadis".

${ }^{7} \mathrm{R}$. Michael Feener, "Indonesian Movements for the Creation of a 'National Madhhab,"' BRILL Journal of Islamic Law and Society 9, no. 1 (2002): 83, https://doi.org/https://doi.org/10.1163/156851902753649298.

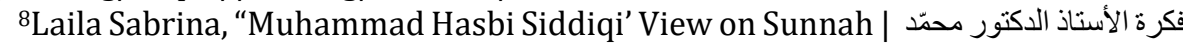
فكرة 2 (2016): 83, https://doi.org/10.15408/zr.v13i2.10672.

${ }^{9}$ Taufan Anggoro, "Analisis Pemikiran Muhammad Syuhudi Ismail Dalam Memahami Hadis," Diroyah: Jurnal Ilmu Hadis 3, no. 2 (2019): 93-104, https://doi.org/https://doi.org/10.15575/diroyah.v3i2.4517.
} 
Indonesian context, such as the hadith of the rain diversion prayer that the Prophet once said, which he considered inappropriate to be read by residents of Jakarta due to differences in geographical context between Jakarta and Medina. ${ }^{10}$

Ali Mustafa also responded to contemporary phenomena in Indonesia with an approach to hadith understanding. This can be seen in his view on the issue of radicalism by explaining moderate Islam from the point of view of the Prophet's hadith. ${ }^{11}$ This approach of hadith understanding is also embedded in educational institutions that he founded with curriculum, methods, and human resources that are formed to give birth to a generation of Islamic leaders with moderate thoughts. ${ }^{12}$ With all his achievements and accomplishments, Ali Mustafa is recognized as one of the hadith experts in Indonesia, and can even be considered as an international hadith expert. ${ }^{13}$ Ali Mustafa has accelerated the understanding of hadith based on the Indonesian context with all its characteristics. ${ }^{14}$

The method of understanding hadith used by Ali Mustafa also cannot be separated from his educational experience while he was in the Middle East, especially Saudi Arabia. On the other hand, Ali Mustafa's understanding of hadith also has a close relationship with his educational experience while in Indonesia which has its own identity because the

\footnotetext{
${ }^{10}$ Anis, "Pemahaman Hadis Doa Pengalihan Hujan Pendekatan Geografis Jakarta Menurut Ali Mustafa Yaqub."

${ }^{11}$ Fatihunnada, "Moderate of Islam Indonesia: Political Views of Indonesia Hadith Scholar," in Proceedings of the 1st International Conference on Recent Innovations, ed. Taqwa Hariguna (Scietpress Digital Library, 2021), 1606-1613, https://doi.org/10.5220/0009932616061613.

12Mohammad Syairozi Dimyathi and Fatihunnada Ilyas, "The Role of Religious Institutions in Preventing Radical Leftism," in Proceedings of the 2nd International Conference on Islam, Science and Technology (ICONIST 2019), ed. Wadim Striełkowski (Atlantis Press, 2020), 24-28, https://doi.org/https://doi.org/10.2991/assehr.k.200220.005.

${ }^{13}$ Nasrullah Nurdin, "Prof. Dr. KH. Ali Mustafa Yaqub, MA.: Muhaddis Nusantara Bertaraf Internasional," Jurnal Lektur Keagamaan 14, no. 1 (2016): 197-228, https://doi.org/https://doi.org/10.31291/jlk.v14i1.481.

14 Muhammad Qomarullah, "Pemahaman Hadis Ali Mustafa Yaqub Dan Kontribusinya Terhadap Pemikiran Hadis Di Indonesia," AL QUDS : Jurnal Studi Alquran Dan Hadis 4, no. 2 (2020): 383, https://doi.org/10.29240/alquds.v4i2.1862.
} 
development of Islam in Indonesia also has local awareness in interpreting religious values from religious texts. ${ }^{15}$

The transmission of hadith studies in Indonesia has been carried out by earlier Nusantara hadith figures such as Muhammad Mahfudz atTarmasi who had transmitted hadith from Haramain to the archipelago in the period between the end of the 19th century and the beginning of the 20th century. He carried out the transmission through students, descendants, pilgrims, printers, and Haramain alumni. This is a response towards the efforts to revitalize the teachings of the Prophet in the archipelago since the second half of the 17 th century with the renewal movement. ${ }^{16}$

From this, it can be seen that the Muhajirin strengthened the paradigm of the genealogy of understanding hadith in Indonesia which was rooted in the land of Haramain from several hadith experts such as Muhammad Mahfudz at-Tarmasi.

Mujiyo states that the genealogy of understanding hadith in Indonesia is developing along with the development of other fields of Islamic studies such as fiqh and fiqh proposals whose main theme is to understand the deep meaning of the Qur'an and hadith that are appropriate to be applied in Indonesia. ${ }^{17}$

Hasep Saputra emphasizes that the genealogy of Ali Mustafa's understanding of hadith comes from various figures in the Middle East such as Mustafa A'zamī in the issue of criticism of the sanad and matan hadith to answer accusations of orientalists, Muhammad Jameel in social issues, and so on when he was educated in Saudi Arabia. In addition, the roots of understanding from classical hadith figures such as Ibn ajar Al'Asqalānī, also color Ali Mustafa's comprehension in understanding the

${ }^{15}$ Miski M. M., "Pemahaman Hadis Ali Mustafa Yaqub Studi Atas Fatwa Pengharaman Serban Dalam Konteks Indonesia," Riwayah 2, no. 1 (2016): 15-31, https://doi.org/10.21043/riwayah.v2i1.1625. dan Azyumardi Azra, Islam Nusantara, Jaringan Global Dan Lokal (Jakarta: Mizan, 2002), 90.

${ }^{16}$ Muhajirin, "Transmisi Hadis Di Nusantara: Peran Ulama Hadis Nusantara Muḥammad Maḥfūz Al-Tarmasī” (UIN Syarif Hidayatullah, 2009), 291-292.

${ }^{17}$ Mujiyo, "Syarah Hadis Dalam Tradisi Keilmuan Islam: Genealogi Dan Metodologi” (UIN Syarif Hidayatullah, 2012). 
hadith about the jurisprudence of worship such as the legal issue of musical instruments. ${ }^{18}$

Miski also detects similarities between Ali Mustafa's understanding of hadith and a modern Middle Eastern religious figure, namely Yūsuf al-Qarad̦āwī. Hadiths with religious nuances are understood textually, while traditions related to social issues such as about local clothing, namely the turban, are understood in a social context. 19

Based on the explanation above, this paper looks back at the genealogical roots of understanding hadith in Indonesia, especially from Ali Mustafa's understanding of the three issues of aqidah, fiqh, and social so that it looks more comprehensive in potraying the genealogical roots of Ali Mustafa's understanding of hadith in Indonesia.

In connection with the description above, this article will discuss how are the genealogical roots of Ali Mustafa's understanding? How is Ali Mustafa's method of understanding in understanding the hadiths about aqidah, worship, and social issues? Furthermore, how do Ali Mustafa's academic experiences during his education in Indonesia and Saudi Arabia affect his understanding of hadith?

The two problems above need to be explained in order to provide a deeper picture of the scholarly network of Nusantara scholars, especially those in the field of hadith. This network will show the roots of thought in understanding hadith through the similarities and differences of Ali Mustafa's methodological understanding of hadith with other classical and contemporary hadith scholars, as well as the characteristics of each method.

This issue is limited to several important issues. In matters of faith, the issue of tawasul is used as the main study to see the understanding of Ali Mustafa's hadith in responding to the ideology originating from the Wahhabi group. In matters of worship, the issue of female imams in

\footnotetext{
18 Saputra, "Perkembangan Studi Hadis Di Indonesia: Pemetaan Dan Analisis Ganeologi," 185-87.

${ }_{19}$ M., "Pemahaman Hadis Ali Mustafa Yaqub Studi Atas Fatwa Pengharaman Serban Dalam Konteks Indonesia," 28.
} 
congregational prayers is the main study to see the understanding of Ali Mustafa's hadith in responding to opinions originating from liberal groups. In social issues, the issue of jihad is the main theme to see Ali Mustafa's understanding in responding to the ideology spread by Radical groups.

In analyzing the problems above, genealogical theory is very relevant to trace the originality of the roots of a character's thoughts in describing the source of religious texts with a methodology. Genealogy itself is a stream of study that focuses on historical values to describe the relationship between science, power, and authority. ${ }^{20}$

Genealogy is a method of discourse or discourse analysis. In the study of sociology, genealogy is a collection of statements that can describe social reality as a focus. Genealogy explores how the flow of power runs behind the social realities of archival records. According to Foucault, genealogy is a discourse method by exercising four principles of power, namely power is a relation, power is diffuse, power is productive, and power works through normalization and regulation. On the other hand, power itself lies somewhere between the "discursive". ${ }^{21}$

This study also uses a synchronic and diachronic approach to see the relationship and influence of Ali Mustafa's thoughts towards other classical and contemporary hadith scholars. Synchronic states (change at a certain moment) will be placed in a diachronic (long-continuous) time frame. This study is strengthened by the Historical-critical method as a historical approach that aims to find objective facts as a whole and look for certain values contained in it. ${ }^{22}$

The main data sources used to explore the above issues are Ali Mustafa's works entitled Female Imam which was written in 2006, Wahabi-NU Meeting Point which was written in 2015, and Islam is Not only for Muslims which was written in 2016. In addition, several 99.

${ }^{20}$ Franz Rosenthal, A History of Muslim Historiography (Leiden: E.J. Brill, 1968),

${ }^{21}$ Michel Foucault, The Archeology of Knowledge and Discourse on Language (London: Tavistock, 1972), 234.

${ }^{22}$ Montgomery Watt, Islamic Fondamentalism and Modernity (London: Routledge, 1988). 
secondary sources used to analyze the problem above are authoritative hadith books such as Șahīh al-Bukhārī, Șahih al-Muslim, Sunan Abī Dāwud, Sunan al-Tirmidzī, Sunan al-Nasāī, Sunan Ibn Majah, Muwatța' Malik, Musnad Ahmad, and Sunan al-Dārimī,, books of classical syarah hadith, and other references related to the development of Islamic conditions in Indonesia.

\section{Results and Discussion}

\section{Ali Mustafa, between NU and Wahabi}

Ali Mustafa grew and thrived among NU community, which is the largest religious community organization in Indonesia. He was born in Kemiri village, Subah District, Batang Regency, Central Java on March 2, 1952. Yaqub is the name of his father and Zulaikha is the name of his mother. Ali Mustafa has seven brothers. Ahmad Dahlan Nuri Yaqub is one of the older brothers who followed in his father's footsteps to devote himself as a caregiver to the Darus Salam Islamic Boarding School in Batang, Central Java. ${ }^{23}$

Ali Mustafa received his education in several Islamic boarding schools such as the Salafiyah Syafiiyah Seblak Islamic Boarding School which was the development of the Tebuireng Islamic Boarding School, the Tebuireng Islamic Boarding School in Jombang. There, he found teachers who he considered as a model, such as KH. Idris Kamali and KH. Syansuri Badawi. He was also influenced by the figure of KH. Hasyim Asy'ari who is a hadith figure of nusantara. These two Islamic boarding schools instilled the NU culture with the Sunni Nusantara ideology in Ali Mustafa's thinking.

At the age of 24, Ali Mustafa received a call to continue his studies at the Faculty of Sharia, Muhammad bin Saud Islamic University in Saudi Arabia and earned a bachelor's degree with a license certificate in 1980. He continued his master degree at King Saud University, Department of Islamic Studies, majoring in Tafsir Hadith, until he graduated with a Master's degree in 1985. These two universities gave Ali Mustafa

${ }^{23}$ M. Alvin Nur Choironi, “Biografi Singkat KH. Ali Mustafa Yaqub,” Islami, 2018, http://www.datdut.com/bukan-wahabi/. 
Wahhabi thought through a learning system and reading resources during his studies. On the other hand, he also met Muhammad Muștafā A'żamī as a teacher who was very inspiring in studying hadith, especially to refute orientalist accusations against the history and authenticity of hadith.

After he returned to his homeland in 1985, he disseminated the knowledge he gained during his education at Indonesian Islamic boarding schools and Saudi Arabian universities. In 2005, he continued his studies at the Doctoral Program (S3) at the University of Nizamia, Hyderabad, India and obtained his doctorate degree in 2008. During this phase, he met Ḥasan Hītū who is a traditional Sunni figure who is very strongly against Wahhabi thought. Therefore, Ali Mustafa got a different academic feel than before. ${ }^{24}$

Ali Mustafa is one of the Indonesian hadith experts who has a considerable influence in the study of hadith in Indonesia. This is evident in several aspects. First, he had produced approximately 29 works that specifically discuss hadith and the science of hadith from the approximately 51 works he had written. Second, he had also established an educational institution that specifically studies hadith named Darus Sunnah International High Institute for Hadith Sciences which was started from a simple study of several students at the Syarif Hidayatullah State Islamic University in Jakarta where he lived. And now, the institution has grown very rapidly including higher education institutions and secondary schools. Third, he earned the highest degree in academics as a Professor in the field of Hadith. ${ }^{25}$

On Thursday, April 24, 2016, Ali Mustafa died and was buried in the Darus-Sunnah area, behind the Muniroh Salamah mosque area at the age of 64 and left a farewell message to all students at the 13th DarusSunnah graduation ceremony, to be exact on the 6th June of $2015 .{ }^{26}$

\footnotetext{
${ }^{24}$ Ulin Nuha Mahfudhon, Biografi Kyai Ali Mustafa Yaqub, Meniti Dakwah Di Jalan Sunnah (Jakarta: Maktabah Darus-Sunnah, 2018), 75-94.

${ }^{25}$ Nurdin, "Prof. Dr. KH. Ali Mustafa Yaqub, MA.: Muhaddis Nusantara Bertaraf Internasional."

${ }^{26}$ Mahfudhon, Biografi Kyai Ali Mustafa Yaqub, Meniti Dakwah Di Jalan Sunnah, 229-31.
} 
Ali Mustafa tried to find common ground between religious rituals and the concept of Islamic teachings between NU and Wahhabis because he had studied in Saudi Arabia which is known as the center of Wahhabism. Ali Mustafa tried this by comparing the main books of $\mathrm{NU}$ and Wahabi. The main book of NU that Ali Mustafa referred to was the book by Hasyim Asy'ari. Meanwhile, the sources of Wahhabi teachings referred to were the works of Ibn Taimyah, Ibn Qayyim, and Muhammad Abd al-Wahhāb.

On the other hand, Ali Mustafa was also strongly against the Wahhabi sect for heresy about NU's religious rituals. Ali Mustafa had experience living in the two cultures of NU and Wahabi (Saudi Arabia), so he knew well the religious rituals of each of the two groups. Therefore, it is inappropriate for some NU circles to discredit themselves as Wahhabi agents. $^{27}$

The book entitled The Wahhabi-NU Meeting Point contains criticisms of the current Wahhabis who do not understand the substance of the NU group's practice, such as tawasul with the name of the prophet Muhammad, pilgrimages to graves, and so on. Therefore, the Wahhabi-NU Meeting Point actually provides evidence that Ali Mustafa is a very strong NU figure, but tries to correct the misunderstandings of the Wahhabi group in a gentle way, as if he is siding with and justifying the Wahhabi group.

With the presence of the book, several NU activists have also submitted other criticisms. These criticisms are welcomed by some of Ali Mustafa's students in several writings. Among the arguments built to reject Ali Mustafa's accusation of being a Wahhabi agent is that Ali Mustafa's daily religious practices are closer to the amaliah of $\mathrm{NU}$ ideology than the amaliah of Wahhabi ideology. Ali Mustafa religious practices were like Yasinan and Tahlilan on Friday nights, visiting graves,

\footnotetext{
${ }^{27}$ Redaksi, "Ini 5 Alasan Orang Syiah Dan Liberal Tidak Suka K.H. Ali Mustafa Yaqub,” Datdut, 2019.
} 
forbidding students from wearing robes, kissing teachers' hands, commemorating the birthday of the prophet Muhammad, and so on. ${ }^{28}$

\section{The Portrait of Ali Mustafa's Hadith Genealogy}

Looking at Ali Mustafa's long educational experience, Ali Mustafa's roots in understanding hadith are very diverse from various figures of Islamic thought groups such as NU, Wahabi, Occidentalism, and so on. This can be seen in the genealogical map as follows:

Pigure 1. Ali Mustafa's Hadith Genealogy

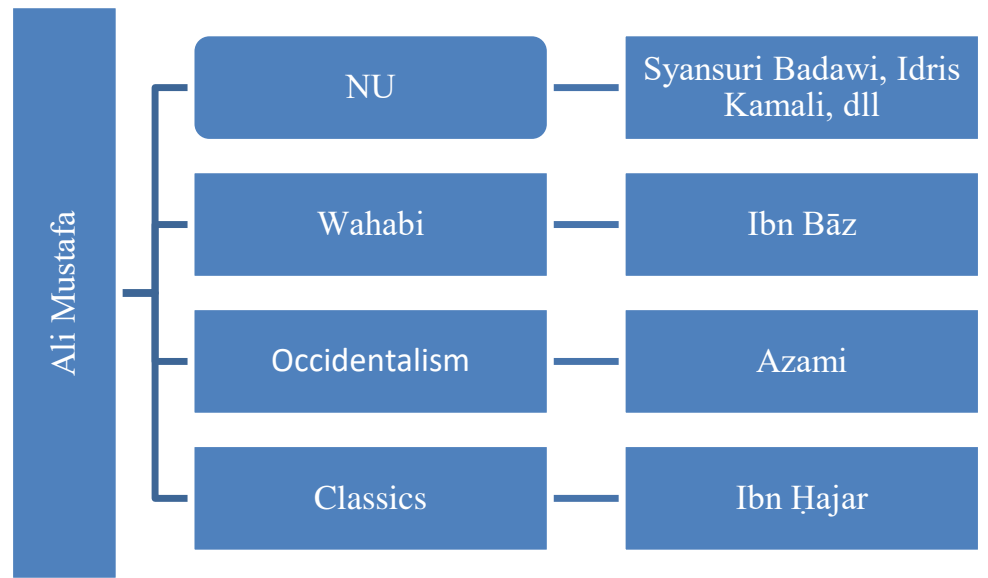

This illustrates that the genealogical roots of Ali Mustafa's understanding are very diverse. He has roots in Nahdlatul Ulama's understanding of his educational experiences at the Seblak and Tebuireng Islamic boarding schools in Indonesia. He also has Wahhabi roots when he continued his education at the tertiary level at the Muhammad bin Saud Islamic University and King Saud University in Saudi Arabia. On the same occasion, he also got the roots of the Occidentalism understanding of hadith. In the course of his educational experience, Ali Mustafa also got the roots of understanding hadith from the authors of the classic Syarah hadith books because the tradition of santri in Islamic boarding schools is identical with reading the yellow book. The study of Ali Mustafa's understanding of hadith on several issues of faith, worship, and social affairs can explain more deeply about the genealogy of his understanding.

28Syifa Fauziyah, "Ini 5 Fakta Tak Terbantahkan Kalau Prof. Dr. K.H. Ali Mustafa Yaqub Bukan Wahabi," Datdut, 2016. Dan Muhammad Ali Wafa, "Benarkah KH Ali Mustafa Yaqub Penganut Paham Wahabi? (1)," Nu Online, 2017. 


\section{Understanding the Hadith of the Female Imam in Salat}

Ali Mustafa argues that it is not permissible for a female imam to pray in a congregation in which there are men in it. He wrote of his anxiety about the deviant phenomenon of a woman leading male congregational prayers. He asserted that for more than fourteen centuries, Muslims practiced their religion in a calm and peaceful manner, but they were shocked by the behavior and views of Amina Wadud who became the imam of Friday prayers with a congregation of men and women. ${ }^{29}$ It turns out that this behavior is sponsored by a group that aspires, among other things, to free Muslim women to do Free-Sex. A number of Amina Wadud's supporters also carry the hadith of Umm Waraqah as a proof for this problem. ${ }^{30}$

Among the hadiths quoted by Ali Mustafa ${ }^{31}$ in affirming his opinion is the hadith about the prophet's clear prohibition on female imams for male congregations in prayer with the following narration:

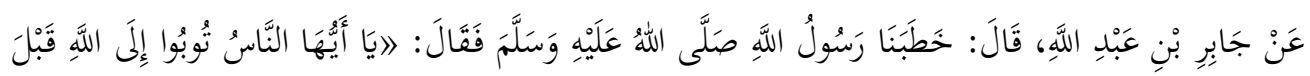

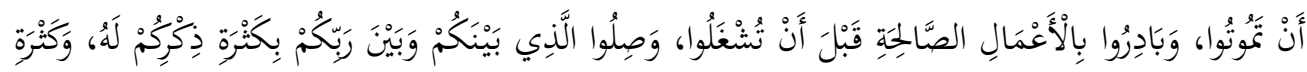

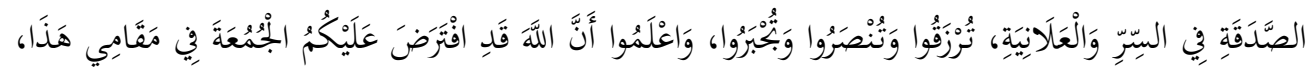

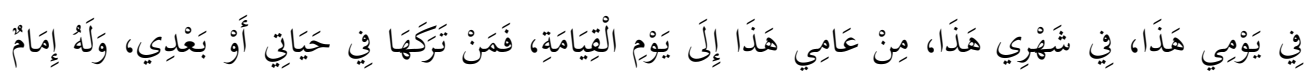

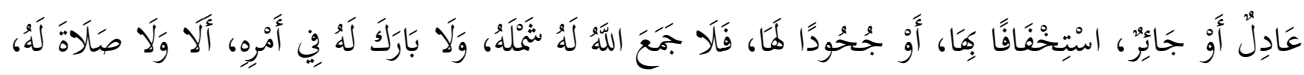

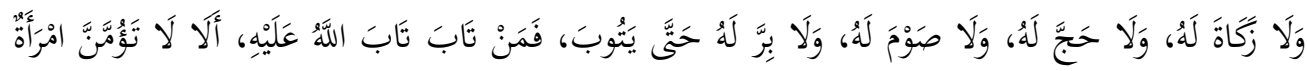

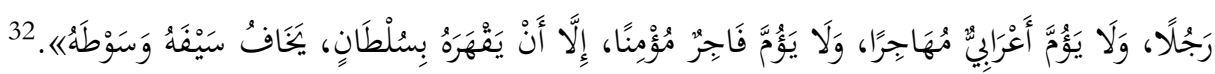

"From Jabir bin Abdullah, he said, "The Messenger of Allah delivered a sermon in front of us, he said: "O people, repent to Allah before you die, hasten to do good deeds before you are busy, and connect between you and your Lord by multiplying remembrance of Him, give alms either in secret or

${ }^{29}$ Syukri dan Muhammad Mutawali Abu Bakar, "Pandangan Amina Wadud Terhadap Perempuan Menjadi Imam Sholat Laki-Laki: Suatu Pendekatan Tafsir $\begin{array}{lllll}\text { Heremeneutik," Scemata 9, no. } 15-32 \text {, } & \text { (2020): }\end{array}$ https://doi.org/https://doi.org/10.20414/schemata.v9i1.1021.

${ }^{30}$ Ali Mustafa Yaqub, Imam Perempuan (Jakarta: Pustaka Firdaus, 2007), 85.

31Yaqub, 24.

${ }^{32}$ Muhammad ibn Yazīd Ibn Mājah, Sunan Ibn Mãjah (Kairo: Dār Iḥyā’ al-Kutub al-'Arabiyyah, n.d.), 1, 343 No. 1081. 
openly, surely you will be provided with sustenance, be helped and be fulfilled. Know that Allah has made it obligatory for you to pray Friday prayer at this place of mine, on this day of mine, in this month of mine, and in this year of mine until the Day of Resurrection. Whoever leaves it in my lifetime or after me, and he has a righteous or corrupt imam, then despises or rejects him, Allah will not unite him, and his affairs will not be blessed. Know that there is no prayer, no zakat, no pilgrimage, no fasting, and no good for him until he repents. So whoever repents, Allah will accept his repentance. Know that it is not permissible for a woman to lead a man, a Bedouin to lead a muhajir, and it is not permissible for a sinner to lead an obedient person, unless he forces him with power with the threat of his sword and whip."

The above hadith shows that it is invalid for a woman to be an imam over a man. ${ }^{33}$ This is the opinion of the majority of scholars. Laws like this are not only taken from this hadith because of the weakness of this hadith, but several other arguments that explain the law.

Thus, Ali Mustafa discussed the hadith further ${ }^{34}$ which is used as the basis by a group that allows women to be the imam of prayers for men with the following narration:

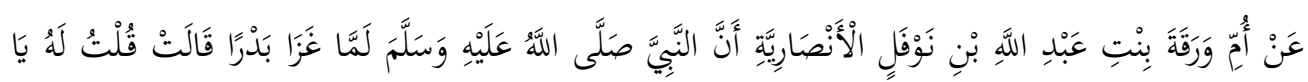

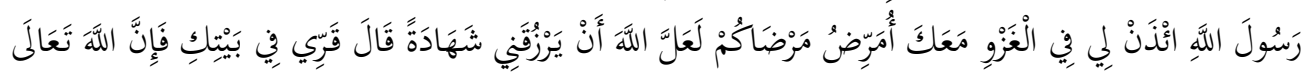

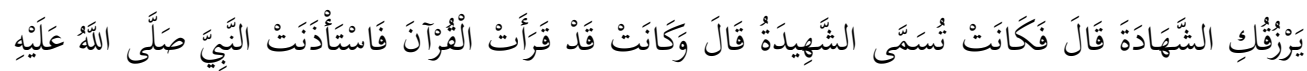

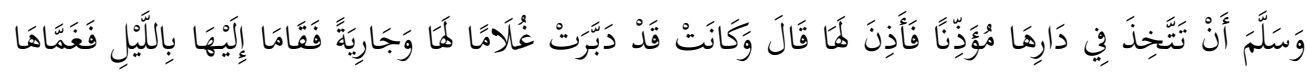

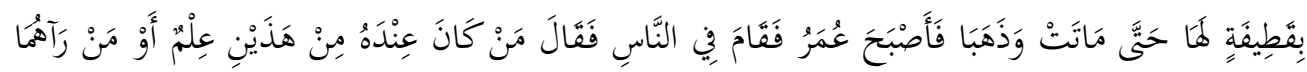

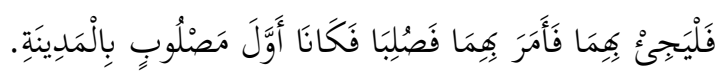

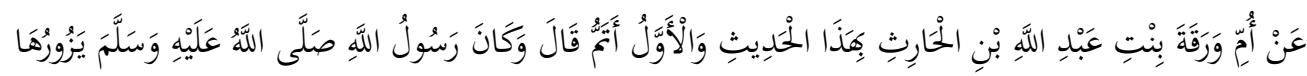

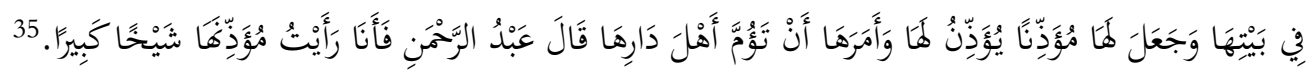

${ }^{33}$ Muhạmmad ibn 'Alī As-Syawkānī, Nayl Al-Awțār (Mesir: Dār al-Ḥadīth, 1993), 3, 194. Dan 'Ả̉bd ar-Raḥmān ibn Aḥmad Ibn Rajab, Fatḥ Al-Bārī Syarḥ Ṣahīḥ Al-Buhkārī (Kairo: Maktab Taḥīq Dār al-Ḥaramain, 1996), 6, 195.

${ }^{34}$ Yaqub, Imam Perempuan, 31.

${ }^{35}$ Sulaimān ibn Asy'as̉ ibn Ishạa Abū Dāwūd, Sunan Abī Dāwūd (Beirut: alMaktabah al-'Așrīyah, n.d.), 1, 161 No. 592. 
"From Umm Waraqah bint Abdillah bin Naufal al-Ansariyah, that she asked the Prophet SAW when she was going to the battle of Badr: O Messenger of Allah, allow me to participate in the war with you to care for sick soldiers. May Allah grant me martyrdom. He replied: "Stay in your homes, verily Allah will grant you martyrdom." The narrator of this hadith said: That is why she is called a shahida. She is also an expert on the Qur'an. After that, she asked the Prophet for permission to be allowed to appoint someone in her house to give the call to prayer, and then the Prophet allowed it. She had changed the status of his two male and female slaves as Mudabbar slaves (slaves who were promised freedom after the death of their master). One night, the two slaves got up and went to her, and covered her face with a cloth until the woman died, while the two slaves fled. On the next day, Umar stood in front of the crowd, and said: Whoever knows these two or sees these two slaves, bring them here! After being caught, they were ordered to be crucified. These two slaves were the first to be crucified in the city of Medina.

In another narration, from Umm Waraqah bint Abdullah bin alHarith with this hadith, but the first one is more complete. She said: Rasulullah SAW once visited her house and he appointed a muadh in the call to prayer for her and allowed Umm Waraqah to be the imam of the family. Abdurrahman said: I saw an old man calling the call to prayer."

There are several interpretations of this hadith. Some scholars explained that Umm Waraqah became the imam of family prayers, and the people who lived in her house were women and small children. Others explain that the makmum referred to in this hadith were not only women and small children, but there was an old man. ${ }^{36}$ This hadith is considered to be one proof of the shift in the role of women in the life of Arab society at the time of the Prophet SAW after women were considered unable to play a role in the life of Arab society during the Jahiliyah era. ${ }^{37}$

${ }^{36}$ Muḥammad Asyraf ibn Amīr al-'Az̄ìm Al-Ābādī, 'Awn Al-Ma'būd Syarḥ Sunan $A b \bar{i}$ Dāwūd (Beirut: Dār al-Kutub al-'Ilmīyah, 1415), 2, 212. Dan As-Syawkānī, Nayl AlAwțār, 3, 196.

37Muhammad Mahsus, "Tafsir Kontekstual Dan Eksistensi Perempuan Serta Implikasinya Terhadap Penyetaraan Bagian Waris Laki-Laki Dan Perempuan," JIL: Journal of Islamic Law 1, no. 1 (2020): 35, https://doi.org/10.24260/jil.v1i1.19. 
From the point of view of authoritative Islamic jurisprudence in the four schools of jurisprudence, the scholars agree that it is haraam for women to become male imams in congregational prayers. ${ }^{38}$

In Female Imam book, Ali Mustafa draws a conclusion regarding the hadith of Umm Waraqah that the hadith which was mentioned as a proposition by Abū aur and al-Muzanī for the issue of female imam turned out to be a weak hadith which could not be used as a proof because it was not corroborated by other narrations. The weak point of this hadith chain is a narrator named al-Walīd ibn Juma'î who is considered a controversial person among hadith experts. Some hadith scholars such as Yahyā ibn Sa'īd, Ibn ibbān, and al-Ḥakim accept his narration, but dispute his character. Abū Dāwūd, Aḥmad, and Abū Zur'ah considered him a fair person, but did not have any shortcomings in his memorization. ${ }^{39}$ Suryadilaga has different opinion. He concludes that this hadith was considered valid because all of its narrators were accepted, including alWalīd ibn Juma'ī. 40

If the hadith is accepted as authentic, then it must be understood by comparing it with other narrations which state that Umm Waraqah was allowed to lead the women in her house. ${ }^{41}$

In this case, Ali Mustafa's thoughts are in conflict with Liberal and Feminist groups such as Husein Muhammad which was published on the Islamlib website under the title "Women may lead men". The article is based on the thoughts of Husein Muhammad who was interviewed by Ulil Abshar in 2005. The approach taken by Husein Muhammad is based on a search for the fiqh opinions of mazhab scholars, including Abū aur, alȚabarī, and al-Muzanī. ${ }^{42}$

38Wahbah Az-Zuhailī, Al-Fiqh Al-Islāmī Wa Adillatuh (Beirut: Dār al-Fikr, 2007), 2, 1194-95. Lihat juga: Ahmad Sarwat, "Wanita Haram Menjadi Imam Buat Laki-Laki," Rumah Fikih Indonesia, 2012, https://rumahfiqih.com/x.php?id=1330332554.

${ }^{39}$ Yaqub, Imam Perempuan, 34-43.

${ }^{40} \mathrm{M}$. Alfatih Suryadilaga, "Hadis-Hadis Tentang Perempuan Sebagai Imam Shalat," Musawa 10, no. 1 (2011): $1-32$, https://doi.org/https://doi.org/10.14421/musawa.2011.101.1-32.

${ }^{41}$ Yaqub, Imam Perempuan, 35.

${ }^{42}$ IslamLib, "Husein Muhammad Perempuan Boleh Mengimami Laki-Laki," IslamLib, 2005. Husein Muhammad, Fiqh Perempuan: Refleksi Kiai Atas Wacana Agama 
Women's leadership has indeed become a debate among scholars, both in the context of congregational prayers and in the context of institutional positions. Issues about the weakness of women's ability to lead men, lack of reason, weakness of faith, superiority of men over women, and so on have become a point of debate between traditionalist and feminist groups. Aș-Ṣan'ānī is one of the figures who reject this permission..$^{43}$

This explains that Ali Mustafa strongly adheres to the jurisprudence of the four schools of thought, especially the Imam Shafi'i School which is the dominant school in Indonesia. The term Indonesian Islam actually refers to the practice of actualizing the teachings of Islam in Indonesia. Even though Indonesian Muslims believe in the pillars of faith and practice the pillars of Islam and other worships that are the same as Muslims in other countries, they have their own distinctiveness in the actualization of their Islamic socio-cultural life which is not found in other countries. Indonesian Muslims have a distinctive social system and tradition by embracing Asy'arīyah and Mātūrīdīyah theology which is complemented by the Shafi'i school of jurisprudence such as the practice of tawassul, pilgrimage to graves, and so on. ${ }^{44}$

Ali Mustafa's understanding cannot be separated from the opinion of Hasyim Asy'ari who said that an adult man should not be a makmum for a female imam. ${ }^{45}$ This type of genealogy of understanding is called by

Dan Gender (Yogyakarta: LKiS, 2001), 32-43. Dan Syamsurijal S., "Kontroversi Imam Perempuan: Studi Maudhu'iy Terhadap Hadist-Hadist Imam Perempuan Dalam Shalat," $\begin{array}{lllll}\text { Al-Fikr 2016, no. } 20 & \text { (n.d.): } 249, & \text { http://journal.uin- }\end{array}$ alauddin.ac.id/index.php/alfikr/article/view/2319.

${ }^{43}$ Fatihunnada and Ulfa Fauziah Anis, "San'ani's View on Women Authority in the Book of Subul Al-Salam | ولاية المرأة عند الصنعاني في سبل السلام', AL-Zahra : Journal for Islamic and Arabic Studies 16, no. 1 (2019): 91-118, https://doi.org/10.15408/zr.v16i1.12281. dan Muhammad ibn Ismā'īl Aṣ-Ṣan'ānī, Subul As-Salām Syarḥ Bulūg Al-Marām (Dammam: Dār ibn al-Jauzī, 1461), 8, 64.

${ }^{44}$ Martin van Bruinessen, "Traditionalist and Islamist Pesantrens in Contemporary Indonesia," in The Madrasa in Asia (Amsterdam: Amsterdam University Press, 2008), 221. Dan Azra, Islam Nusantara, Jaringan Global Dan Lokal.

${ }^{45}$ Hāsyim Asy'arī, "Jāmi'at Al-Maqāṣid Fī Bayān Mabādi' Al-Tawhīd Wa Al-Fiqh Wa Al-Tașawwuf Li Al-Murīd," in Irsyād Al-Sārī Fì Jam' Mușannafāt Al-Syaykh Hāsyim Asy'arī (Jombang: Al-Maktabah al-Masrūrīyah, n.d.), 18. 
Foucault as a form of succession. ${ }^{46}$ Ali Mustafa gave an explanation of the law of a woman who became imam of prayer for men with an explanation of figh in the four schools of thought and a description of the hadith that described the case of a woman becoming a male imam at the time of the Prophet. Hasyim Asy'ari is the founding figure of $\mathrm{NU}$ who is a representative of the religious thought of the Nahdlatul Ulama community.

On the other hand, Ali Mustafa also based his understanding of classical scholars such as Imam Shafi'i in the field of fiqh and classical hadith scribes such as Ibn Rajab, ${ }^{47}$ al-Qasțalānī ${ }^{48}$ and others.

\section{Understanding Tawassul Hadith with Prophet Muhammad}

In reviewing this matter, Ali Mustafa begins by quoting the opinion of Ibn Taimīyah in his Majmū' Fatāwā al-Imām Ibn Taimīyah that it is permissible to repent in the name of the prophet Muhammad. Ibn Taimyah does not use the term tawasul with the name of the prophet Muhammad, but uses the term repentance. Ali Mustafa saw that this was no different, so he reviewed tawasul in the name of the prophet Muhammad with a quote from Ibn Taimìyah's opinion. According to him, repenting is included in the category of praying with tawasul. ${ }^{49}$

Ibn Taimiyah is a main figure of Wahhabism because many Wahhabi-Salafi groups base their opinions on Ibn Taimìyah. ${ }^{50}$ Not only in the matter of tawasul, the Wahhabi-Salafi group also quoted Ibn Taimiyah 's opinion on several issues such as visiting graves and so on. ${ }^{51}$ In addition

46Foucault, The Archeology of Knowledge and Discourse on Language, 108.

${ }^{47}$ Ibn Rajab, Fatḥ Al-Bārī Syarh Șaḥịh Al-Buhkārī, 6, 195.

${ }^{48}$ Aḥmad ibn Muḥammad al-Qasțalānī, Irsyād Al-Sārī Li Syarḥ Șaḥịh Al-Buhkārī (Kairo: Al-Mațba'ah al-Kubrā al-Amīrìyah, 1323), 5, 238.

${ }^{49}$ Ali Mustafa Yaqub, Titik Temu Wahabi-NU (Jakarta: Maktabah Darus-Sunnah, 2016), 57. Dan Ahmad ibn 'Abd al-Ḥalīm al-Ḥarranī Ibn Taimīyah, Majmú' Al-Fatāwā (Madinah: Majma' al-Malik Fahd, 1995), 2, 150.

${ }^{50}$ Mansur Mangasing, "Muhammad Ibn 'Abd Al-Wahhab Dan Gerakan Wahabi,"

$\begin{array}{lllll}\text { Jurnal Hunafa } & 5, & \text { no. } & & \end{array}$ https://doi.org/https://doi.org/10.24239/jsi.v5i3.181.319-328.

${ }^{51} \mathrm{~A} . \mathrm{G}$. Muhaimin, The Islamic Traditions of Cirebon: Ibadat and Adat Among Javanese Muslims (Canberra: ANU E Press, 2006), 159. Dan Hamza Mustapha, The AlNusra Front: From Formation to Dissension (Doha: Arab Center for Research and Policy Studies, 2014), 1. 
to the Wahhabi group from the Salafis, the Salafi Jihadi group also refers a lot to the opinion of Ibn Taimiyah from the classical community to strengthen their ideology. ${ }^{52}$ Ali Mustafa also refers a lot to the work of alAlbani in the study of hadith. ${ }^{53}$

The practice of tawassul agreed upon by every Islamic religious group is tawassul with good deeds that have been done. This is illustrated by a person's request to Allah SWT through the intermediary of good deeds that he has done in the past, such as serving his parents, giving charity, helping others in need, praying at night, sunnah fasting, reading the Qur'an, performing Umrah. , Hajj, and so on. ${ }^{54}$

In practice, tawasul with the prophet Muhammad is read in religious activities of the Indonesian Muslim community in commemorating the death of someone in a series of tahlilan readings..$^{55}$ It is believed that apart from being able to provide benefits/reward to the deceased, it can also have a positive impact on the performers of the rituals presented from the aspects of belief, worship, and morals.

Ali Mustafa quoted Ibn Taimìyah 's explanation which states that the hadith of the repentance of the prophet Adam under the name of the prophet Muhammad was narrated by several hadith narrators. Imam Ibn Taimiyah said: "It is narrated that Allah wrote his name (name of Muhammad) on the Throne (Arasy) and the objects in Paradise, namely doors, qubah and leaves. In this case, there are many narrations that are in line with authentic hadiths that explain repentance in the name of Muhammad and exalt its mention at that time". ${ }^{56}$

${ }^{52}$ Mordechai and David Yerushalmi Kedar, "Sharia Adherence Mosque Survey: Correlations between Sharia Adherence and Violent Dogma in U.S. Mosques," $\begin{array}{llllll}\text { Perspectives on Terrorism 5, no. 5-6 } & \text { (2011): }\end{array}$ http://www.terrorismanalysts.com/pt/index.php/pot/article/view/shariaadherence-mosque-survey.

${ }^{53}$ M. Rizki Syahrul Ramadhan, "Metode Kritik Hadis Ali Mustafa Yaqub; Antara Teori Dan Aplikasi," Nabawi: Journal of Hadith Studies 1, no. 1 (2020): 39-40.

${ }^{54}$ Desri Nengsih, "Tawassul Dalam Perspektif Hadis (Kajian Terhadap Hadis Kisah Tiga Pemuda Terperangkap Dalam Goa)," Jurnal Ulunnuha 9, no. 1 (2020): 74-92. ${ }^{55}$ Jerry Hendrajaya and Amru Almu'tasim, "Tradisi Selamatan Kematian Nyatus Nyewu: Implikasi Nilai Pluralisme Islam Jawa," Jurnal Lektur Keagamaan 17, no. 2 (2019): 445, https://doi.org/10.31291/jlk.v17i2.756.

${ }^{56}$ Yaqub, Titik Temu Wahabi-NU, 58. 
Overall, the hadiths about this have a degree of authenticity. The following hadiths are considered mutually reinforcing to achieve the degree of authentic hadith.

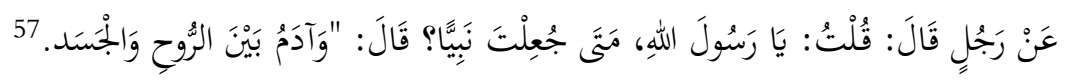

"A friend asked the prophet: $O$ Messenger of Allah, when did you become a prophet? The prophet replied: when the prophet Adam was still between the spirit and the body."

According to al-Albani, this hadith falls into the category of daif or weak. 58

The meaning of this hadith has several views among scholars. Some scholars understand this hadith that Allah created the souls before the body. Therefore, the words of the Prophet "I have become a prophet" above are a sign to the spirit of the Prophet, not the body. The essence of prophethood is known only by Allah and Allah's chosen people. The essence of prophethood is also only given to people who are chosen by Allah at the time appointed by Allah. Therefore, the prophethood of the prophet Muhammad existed before the creation of the prophet Adam. After the prophet Muhammad was born, the prophetic traits were born and given by Allah to the prophet Muhammad. ${ }^{59}$

Ibn Hajar al-Haitamì mentions several other understandings of the scholars. Among them is that the prophethood of Muhammad was created in the spirit world earlier than the creation of the prophet Adam. This means that the creation of Muhammad as a prophet was already famous in the realm of spirits among the Angels. Another opinion says that the prophethood of Muhammad existed before the creation of the prophet Adam in the knowledge of Allah. Another opinion comes from al-Gazāli who asserts that the meaning of this hadith is that the prophet Muhammad had already become a prophet than the creation of the

\footnotetext{
${ }^{57}$ Ahmmad ibn Muhḥammad ibn Ḥanbal As-Syaibānī, Musnad Al-Imām Aḥmad Ibn Hanbal (Beirut: Mu'assasah ar-Risālah, 2001), 27, 176 No. 16623.

58Muhammad Nāṣir al-Dīn ibn al-Ḥājj Nūḥ Al-Albānī, Silsilat Al-Ahāāīs AḍDa'îfah Wa Al-Mauḍ̄̄AAh Wa Aśaruhā as-Sayyi' Fī Al-Ummah (Riyadh: Dār al-Ma'ārif, 1420), 1, 474; 2, 115; 12, 468; dan 12, 469.

59‘Abd al-Raḥmān ibn Abī Bakr As-Suyūṭī, Al-Hāāwì Li Al-Fatāwā (Beirut: Dār alKutub al-'Ilmīyah, 2004), 2, 100-101.
} 
prophet Adam in destiny, not in creation, while in creation, the prophet Adam was born before the prophet Muhammad. 60

Furthermore, Ali Mustafa explains Hasyim Asy'ari's opinion by explaining the similarities between Hasyim Asy'ari and Ibn Taimìyah. In comparing and unifying the opinions of Hasyim Asy'ari and Ibn Taimiyah, Ali Mustafa also received criticism from Nur Khalik Ridwan (2015) that Hasyim Asy'ari himself viewed Ibn Taimīyah and Muhammad 'Abd alWahhāb as people who forbid what the muslim people agreed upon.

This can be seen in the book of Aswaja's Treatise ${ }^{61}$ which mentions: "Traditional groups that still exist hold fast to the doctrines desired by the salafush sholih, adhere to one particular school of thought, adhere to the circulating mu'tabarah books, love the stanza experts, the saints, and pious people, hope blessing for those who are still alive and those who have died, perform rituals of worship such as pilgrimage to the grave, mentalqin for the dead, shadaqah for the dead, and believe in intercession or help, the benefits of prayer, doing tawasul, and so on".62

Ali Mustafa has an opinion that is close to NU ideology, such as the results of a study by the Bahtsul Masail NU Institute from the Salafiyah Syafi'iyah Islamic Boarding School Nurul Huda Mergosono Malang63

about the permissibility of tawasul because of the miracles of the prophets, the Karāmah of the guardians, and the Ma'unah of the pious scholars were not interrupted by their death. This was confirmed by Yūsuf ibn Isḥāq an-Nabhānī in the book of Syawāhid al-Ḥaqq as follows:

${ }^{60}$ Aḥmad ibn Muḥammad Ibn Hajar Al-Ḥaitamī, Asyraf Al-Wasā'il Ilā Fahm asSyamā'il (Beirut: Dār al-Kutub al-'Ilmīyah, 1998), 34-35.

${ }^{61}$ Hāsyim Asy'arī, "Risālat Ahl Al-Sunnah Wa Al-Jamā'ah," in Irsyād Al-Sārī Fī Jam' Mușannafāt Al-Syaykh Hāsyim Asy'arī (Jombang: Al-Maktabah al-Masrūrīyah, n.d.), 9.

${ }^{62}$ Nur Khalik Ridwan, "Tanggapan Atas Tulisan KH Ali Mustafa Yaqub Soal Wahabi-NU," Nu Online, 2015.

${ }^{63}$ Admin, "Tahlil Dan Tawasul Untuk Mayit," Nurul Huda, accessed February 11, 2021, https://ppssnh.malang.pesantren.web.id/cgibin/content.cgi/masail/aula/tahun_1996/05.single. 


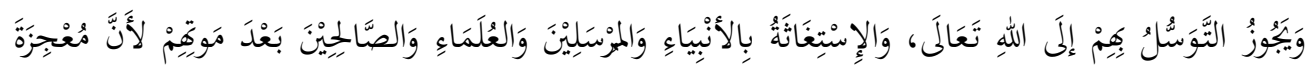

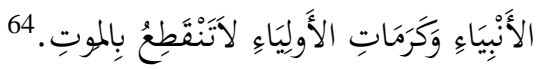

"It is permissible to rely on them (the prophets and guardians) to ask Allah, and they may ask for help through the intermediaries of the Prophets, Apostles, scholars and pious people after they died because of the miracles of the Prophets and the Karomah of the guardians were not cut off by death."

In this matter, Ali Mustafa are at odds with the Wahhabis. His opinions and comments strongly oppose Wahhabi accusations of NU worship practices such as tawasul in the name of the prophet Muhammad which are considered heretical, shirk, and infidels.

If we look more deeply, actually the Wahabi-NU Meeting Point book is an attempt to straighten out Wahhabi accusations against some of NU's worship practices. Therefore, his thoughts on this issue are not in line with the thoughts of the Wahhabi group that has spread among Indonesian Muslims recently.

This confirms that Ali Mustafa has NU ideological roots that allow and encourage the practice of tawasul in the name of the Prophet Muhammad in particular, or in the name of pious people and guardians in general by adhering to Ash'arīyah and Mātūrīdīyah theology which is complemented by the Imam Shafi'i school of fiqh. ${ }^{65}$ The tradition of scientific transmission in NU's intellectual culture is very strong in figures and institutions such as Bahtsul Masail NU to preserve Islamic teachings through the continuity of thoughts and ways of thinking from classical scholars. ${ }^{66}$

${ }^{64}$ Yūsuf ibn Ishāa An-Nabhānī, Syawāhid Al-Haqq Fī Al-Istigāṡah Bi Sayyid AlKhalq (Beirut: Dār al-Kutub al-'Ilmīyah, 2007), 118.

${ }^{65}$ Azyumardi Azra, "Islam Indonesia: Kontribusi Pada Peradaban Global,"

Prisma

29 ,

no.

4

(2010):

83-91,

https://www.prismajurnal.com/issues.php?id=54666a8e-56c0-11e3-a6cc-

429e1b0bc2fa\&bid=29ac1eea-56b8-11e3-a6cc-429e1b0bc2fa.

${ }^{66}$ Hilmy Pratomo, "Transformasi Metode Bahtsul Masail Nu Dalam Berinteraksi

Dengan Al-Qur'an," Jurnal Lektur Keagamaan 18, no. 1 (2020): 132, https://doi.org/10.31291/jlk.v18i1.620. 
Ali Mustafa's understanding cannot be separated from the opinion of Hasyim Asy'ari who says that tawassul is one of the traditions of the Aswaja group. This type of genealogical understanding is called by Foucault as a form of succession. Ali Mustafa gives an explanation of the law of tawassul with a description of the hadith that describes the prophet Adam pleading with Allah by mentioning the name of the prophet Muhammad as a form of tawassul. Hasyim Asy'ari is the founding figure of NU who is a representative of the religious thought of the Nahdlatul Ulama community who has the character of ahlus sunnah wal-jama'ah.

\section{Understanding the Hadith of Jihad and Terrorists}

Ali Mustafa argues that the terrorist behavior that recently occurred in Indonesia such as the Bali bombings and others is not included in the practice of jihad according to Islam. Ali Mustafa has considerable attention to the phenomenon of radicalism and terrorism in Indonesia. ${ }^{67}$

The Bali bombing was one of a series of terrors that occurred in Indonesia in the name of religion. The terror that made several other countries increased their anticipation of the emergence of terror in their countries. Australia was one of the countries that had taken steps to be prepared to deal with potential terrors such as the Bali bombings which injured 75 Australian citizens in Bali. ${ }^{68}$ This act of terror is not only aimed at spreading terror in the community, but also to gain financial benefits through the internet. 69

The main hadith which is used as the basis for discussing the concept of jihad in Islam is the hadith about the absence of jihad after the hijrah period with the following narration:

${ }^{67}$ Adriansyah Nz, "Shifting Paradigm Pemahaman Hadis Di Indonesia (Studi Interpretasi Kontekstual Ali Mustafa Ya'Qub Terhadap Hadis-Hadis Hubungan Dengan Non-Muslim)," Jurnal Ilmu Agama: Mengkaji Doktrin, Pemikiran, Dan Fenomena Agama 20, no. 2 (2019): 2019, https://doi.org/10.19109/jia.v20i2.5077.

${ }^{68}$ Paul Barnes, "North of 26 South and the Security of Australia, Views from The Strategist," Australian Strategic Policy Institute, 2019, 11-12, https://www.jstor.org/stable/resrep23032.

${ }^{69}$ Louise I. Shelley, "Illicit Trade and Terrorism," Perspectives on Terrorism 14, no. 4 (2020): 9, https://www.jstor.org/stable/26927661. 


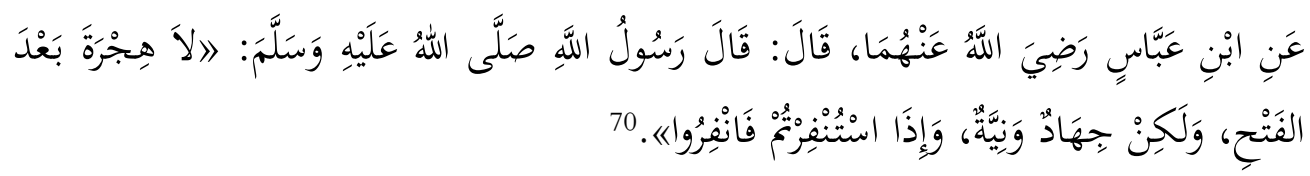

"There is no emigration (hijrah) after the conquest of Mecca, but the obligation of jihad and intention. And if you are asked to run, then run."

In addition to the hadith about jihad and hijrah above, Ali Mustafa also discusses other traditions related to the concept of jihad during war in Islam ${ }^{71}$ with the following narration:

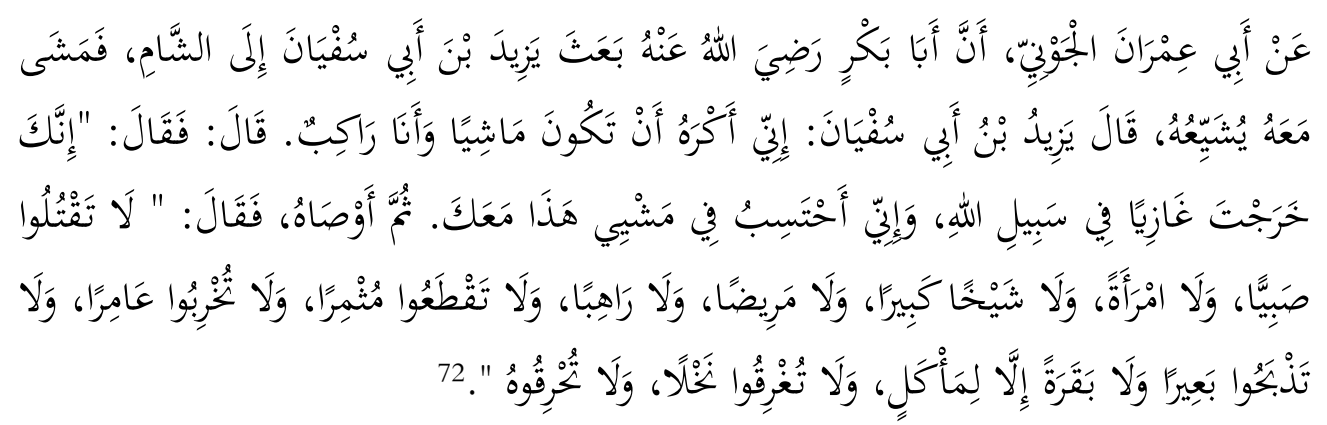

"Abu Bakar sent Yazid ibn Abi Sufyan to the land of Sham, then he walked with him to escort him. Yazid ibn Abi Sufyan said, "Indeed, I do not like you walking, while I am riding a horse. He (the narrator of the hadith) said, and then Abu Bakar replied: Verily you will go out to fight in the way of Allah, while I seek reward when walking with you. Then Abu Bakar advised him by saying: Do not kill children, women, old people, sick people and priests. Do not cut down fruit trees. Don't damage the building. Do not slaughter a camel or a cow except for food. Don't drown the wasp's nest and burn it."

The two hadiths above do provide an illustration that jihad is a teaching of the Islamic religion that is still recommended, including jihad by waging war against religious enemies. ${ }^{73}$

In his view of terrorists, Ali Mustafa tries to provide a deep understanding of the Islamic response to Jihad and terrorists because most people think that this terrorist movement stems from an

${ }^{70}$ Ibn Mājah, Sunan Ibn Mājah, 4, 15 No. 2783.

${ }^{71}$ Yaqub, Islam Is Not Only for Muslims, 147.

${ }^{72}$ Aḥmad ibn al-Ḥusain ibn 'Alī Al-Baihaqī, As-Sunan Al-Kubrā (Beirut: Dār alKutub al-'Ilmīyah, 2003), 9, 153 No. 18152.

${ }^{73}$ Aḥmad ibn 'Alī Ibn Ḥajar Al-'Asqalānī, Fatḥ Al-Bārī Syarḥ Ṣaḥịh Al-Bukhārī (Beirut: Dār al-Ma'rifah, 1397), 6, 39. 
understanding of the concept of Jihad in Islam, so they attach the label of terrorists to Islam only because of the behavior of some muslims who understands Jihad from his own point of view. It is also used by news media to improve the reputation of newspapers by framing several issues related to terror and Islam. ${ }^{74}$

On the other hand, suicide bombers in terrorist activities also believed that the terror they carry out was a jihadi behavior that will give honor to themselves with the label of martyrdom. ${ }^{75}$ This illustrates that terrorists actually do not understand the concept of jihad in Islam well, let alone understand well the texts of the Qur'an and hadith that discuss jihad, so they are easily provoked to commit acts of terror only with the lure of heaven. ${ }^{76}$

Ali Mustafa tries to explain the true concept of jihad in Islam by mentioning three striking differences between Jihad and terrorism in Islam, 1) Jihad in Islam is obligatory, while terrorism in Islam is haraam; 2) Jihad in Islam must be based on orders from a leader or president, while terrorism can be carried out by individuals without obtaining permission and orders from the leader or president; and 3) Jihad in Islam has provisions that must be obeyed, such as not being allowed to fight civilians who do not participate in fighting Islam, meaning that only people who are fighting Islam can be fought and killed, while terrorists will justify any means to achieve their goals by fighting and killing everyone indiscriminately and for a definite reason. ${ }^{77} \mathrm{~A}$ comprehensive method of several narrations was carried out by Ali Mustafa in understanding the hadiths about jihad, terror, and intolerance of

${ }^{74} \mathrm{P}$. Ari Subagyo, "Representasi Frame Dalam Latar Belakang Wacana Tajuk Tentang Terorisme," Litera: Jurnal Penelitian Bahasa, Sastra, Dan Pengajarannya 15, no. 1 (2016): 173-88, https://doi.org/https://doi.org/10.21831/ltr.v15i1.9777.

${ }^{75}$ Herlina dan Ahmad Ali Nurdin Nurani, "Pandangan Keagamaan Pelaku Bom Bunuh Diri Di Indonesia," Journal of Islamic Studies and Humanities 3, no. 1 (2018): 99100, https://doi.org/https://doi.org/10.21580/jish.31.2936. dan Ali Mustafa Yaqub, Ijtihad, Terorisme, Dan Liberalisme (Jakarta: Pustaka Firdaus, 2015), 51.

${ }^{76}$ Agus Handoko, "Analisis Kejahatan Terorisme Bergedok Agama," Salam 6, no. 2 (2019): 176, https://doi.org/https://doi.org/10.15408/sjsbs.v6i2.11041.

${ }^{77}$ Yaqub, Islam Is Not Only for Muslims, 146-47. 
interactions with other religious groups. ${ }^{78}$ The meaning of the jihad hadith according to Ali Mustafa has received the spotlight of hadith reviewers because the misunderstanding of the concept of jihad in Islam can lead to a bad assessment of Islamic teachings. ${ }^{79}$

In this case, Ali Mustafa Yaqub can provide the right answer to the accusations of some observers who view Islam as a terrorist religion. He also provides a deep understanding of the true concept of Jihad in Islam, so that it can be understood by the Indonesian Muslim community. Therefore, they are able to maintain the existence of moderate Indonesian Islam, and understand that it is not easy to spill the blood of fellow human beings on the basis of religious differences. Since several suicide bombings in the Bali I and II bombings, the Marriot Hotel, the Ritz Carlton, the Medan bombing, the Sigi attack, the Makasar Cathedral church bombing, and other suicide bombings, Indonesian people have begun to discuss the concept of Jihad in Islam. This theme seems to be a daily consumptive topic that really needs to be emphasized, considering that the Jihad ideology of radical groups still persists in Indonesia. ${ }^{80}$

In this matter, Ali Mustafa has opposing thoughts with radical groups such as Laskar Jihad (LJ), East Indonesia Mujahidin (MIT), Jamaah Ansharud Daulah (JAD), and others who have entered Indonesia, although they have not shown a terrorist movement. ${ }^{81}$ Ali Mustafa strongly criticized jihadist groups in Indonesia because of a misunderstanding in understanding the hadith, so that actions appeared in the name of jihad, then resulted in creating Islamophobia in Indonesia. ${ }^{82}$

Jihadist groups also use the bai'at hadith to instill doctrinalism of their followers. Bai'at is a symbol of one's religious submission to the

${ }^{78}$ Azis Arifin, "Penerapan Metode Ali Mustafa Yaqub Dalam Memahami Hadis Intoleransi Antar Umat Beragama," Jurnal Holistic Al-Hadis 6, no. 1 (2020): 14-17.

${ }^{79}$ Lasman Azis, “Jihad Perspektif Hadis," Al-Tasyri'iy 2, no. 1 (2019): 1-8.

${ }^{80}$ Harris Yonatan Parmahan Sibue, "Upaya Penanggulangan Terorisme Di Indonesia," Isu Sepekan 1 , no. 1 (2021), https://berkas.dpr.go.id/puslit/files/isu_sepekan/Isu Sepekan---I-P3DI-April-2021215.pdf.

${ }^{81} \mathrm{~V}$ Arianti and Nur Aziemah Azman, "The IS Threat in Indonesia," Counter Terrorist Trends and Analyses 11, no. 7 (2019): 2-4.

${ }^{82}$ Asena Karipek, "Portrayals of Jihad: A Cause of Islamophobia," Islamophobia Studies Journal 5, no. 2 (2020): 214, https://doi.org/10.13169/islastudj.5.2.0210. 
leader. If a person does not take bai'at in his life, then he is declared dead in a state of being lost. ${ }^{83}$

Ali Mustafa is heavily influenced by the NU ideology in fighting the radical ideology that developed in Indonesia. Muhammadiyah and Nahdlatul Ulama (NU) are examples of the most productive organizations to oversee dialogue among the Islamic community with a view for tackling and resisting attacks from radicalism. ${ }^{84}$

Ali Mustafa's understanding cannot be separated from the opinion of Hasyim Asy'ari who says that the Khawarij group which is the root of the understanding of radical and terrorist groups is a deviant group that misunderstands the concept of jihad in Islam. ${ }^{85}$ This type of genealogical understanding is called by Foucault as a form of succession. ${ }^{86}$ Ali Mustafa gives an explanation of the law of jihad with the practice of terror with a description of the hadith about the concept of jihad on the battlefield in Islamic teachings and the hadith about the rules for carrying out jihad orders on the battlefield. Hasyim Asy'ari is the founding figure of NU who is a representative of the religious thought of the Nahdlatul Ulama community who has the moderate Ahlus Sunnah wal-Jama'ah character in understanding Islamic teachings.

\section{Conclusion}

The genealogy of Ali Mustafa's understanding is strongly influenced by several sources such as NU, Wahabi, Occidentalism, and the understanding of classical scholars. NU through its main figure, Hasyim Asy'ari, becomes the dominant source for understanding Ali Mustafa's hadith, especially on issues of aqidah and fiqh. In social issues such as jihad, Ali Mustafa still has roots in NU's understanding which is strong with moderate character.

Ali Mustafa tried to understand the hadith in stages, started with the textual method to maintain the authenticity of the revelation in the

${ }^{83}$ Carlos Igualada and Javier Yagüe, "The Use of Bay'ah by the Main SalafiJihadist Groups," Perspectives on Terrorism 15, no. 1 (2021): 45.

84Tarmizi Taher, Membendung Radikalisme (Jakarta: CMM Press, 2004), 5.

${ }^{85}$ Hāsyim Asy'arī, "Risālat Ahl Al-Sunnah Wa Al-Jamā'ah," 24.

${ }^{86}$ Foucault, The Archeology of Knowledge and Discourse on Language, 108. 
hadith when it was spoken by the Prophet, then continued with the contextual method to provide a more rational understanding when the hadith was put into practice. Contextualization of hadith is an attempt to understand religious texts comprehensively by comparing them to the texts of the Qur'an and other traditions and paying attention to the conditions of the birth of hadith and contextual conditions, so that it provides a picture of understanding of the matters which is difficult to understand. If this step is not taken when understanding the text, then it is considered as leading opinion on religious texts.

Ali Mustafa was influenced by current development in understanding hadith contextually by referring to aspects outside the hadith text such as the causes of the birth of hadith, local and temporal, sentence causality, and socio-cultural. On the other hand, Ali Mustafa was also heavily influenced by the Nahdlatul Ulama ideology which adheres to the Shafi'iyah school of jurisprudence and the Ash'ariyah and Maturidiyah beliefs, and has moderate principles in religion. Therefore, the influence of Ali Mustafa's education in Indonesia through Islamic boarding schools is stronger than his educational experience in Saudi Arabia.

\section{Bibliography}

Abu Bakar, Syukri dan Muhammad Mutawali. "Pandangan Amina Wadud Terhadap Perempuan Menjadi Imam Sholat Laki-Laki: Suatu Pendekatan Tafsir Heremeneutik." Scemata 9, no. 1 (2020): 15-32. https://doi.org/https://doi.org/10.20414/schemata.v9i1.1021.

Abū Dāwūd, Sulaimān ibn Asy'aś ibn Isḥāq. Sunan Abī Dāwūd. Beirut: alMaktabah al-'Așrīyah, n.d.

Admin. "Tahlil Dan Tawasul Untuk Mayit." Nurul Huda. Accessed February 11, 2021. https://ppssnh.malang.pesantren.web.id/cgibin/content.cgi/masail/aula/tahun_1996/05.single.

Aḥmad ibn Muḥammad al-Qasțalānī. Irsyād Al-Sārī Li Syarḥ Șạ̣ị̣ AlBuhkārī. Kairo: Al-Mațba'ah al-Kubrā al-Amīrīyah, 1323.

Al-Ābādī, Muḥammad Asyraf ibn Amīr al-'Aẓ̄m. 'Awn Al-Ma'būd Syarh Sunan Abī Dāwūd. Beirut: Dār al-Kutub al-'Ilmīyah, 1415. 
Al-Albānī, Muḥammad Nāṣir al-Dīn ibn al-Ḥājj Nūḥ. Silsilat Al-Ahādīis AḍDaî̃fah Wa Al-Maudū'Ah Wa Aśaruhā as-Sayyi' Fì Al-Ummah. Riyadh: Dār al-Ma'ārif, 1420.

Al-Baihaqī, Ahmad ibn al-Ḥusain ibn 'Alī. As-Sunan Al-Kubrā. Beirut: Dār al-Kutub al-'Ilmīyah, 2003.

Al-Ḥaitamī, Aḥmad ibn Muḥammad Ibn Ḥajar. Asyraf Al-Wasā'il Ilā Fahm as-Syamā'il. Beirut: Dār al-Kutub al-'Ilmīyah, 1998.

Al-'Asqalānī, Aḥmad ibn 'Alī Ibn Ḥajar. Fatḥ Al-Bārī Syarḥ Ṣaḥịh AlBukhārī. Beirut: Dār al-Ma'rifah, 1397.

Al-Qaraḍāwī, Yūsuf. Al-Khașāiș Al-'Āmmah Li Al-Islām. Beirut: Mu'assasah ar-Risālah, 1977.

An-Nabhānī, Yūsuf ibn Isḥāq. Syawāhid Al-Haqq Fī Al-Istigāsah Bi Sayyid Al-Khalq. Beirut: Dār al-Kutub al-'Ilmīyah, 2007.

Anggoro, Taufan. "Analisis Pemikiran Muhammad Syuhudi Ismail Dalam Memahami Hadis." Diroyah: Jurnal Ilmu Hadis 3, no. 2 (2019): 93104.

https://doi.org/https://doi.org/10.15575/diroyah.v3i2.4517.

Anis, Fatihunnada and Afaf Nazrat Uyun. "Pemahaman Hadis Doa Pengalihan Hujan Pendekatan Geografis Jakarta Menurut Ali Mustafa Yaqub." ILMU USHULUDDIN 7, no. 1 (2020): 37-56. https://doi.org/https://doi.org/10.15408/iu.v7i1.14698.

Anis, Fatihunnada and Ulfa Fauziah. "San'ani's View on Women Authority in the Book of Subul Al-Salam | ولاية المر أة عند الصنعاني في سبل السلام' AL-" Zahra : Journal for Islamic and Arabic Studies 16, no. 1 (2019): 91118. https://doi.org/10.15408/zr.v16i1.12281.

Arianti, V, and Nur Aziemah Azman. "The IS Threat in Indonesia." Counter Terrorist Trends and Analyses 11, no. 7 (2019): 1-5.

Aṣ-Ṣan'ānī, Muḥammad ibn Ismā'īl. Subul As-Salām Syarḥ Bulūg AlMarām. Dammam: Dār ibn al-Jauzī, 1461.

As-Sibā'ī, Mușțafā. As-Sunnah an-Nabawīyah Wa Makānatuhā Fī at-Tasyrī‘ Al-Islāmī. Beirut: Dār al-Kutub al-'Ilmīyah, 2004. 
As-Suyūțī, 'Abd al-Raḥmān ibn Abī Bakr. Al-Ḥ̂̄wī Li Al-Fatāwā. Beirut: Dār al-Kutub al-'Ilmīyah, 2004.

As-Syaibānī, Aḥmad ibn Muhḥammad ibn Ḥanbal. Musnad Al-Imām Aḥmad Ibn Hanbal. Beirut: Mu'assasah ar-Risālah, 2001.

As-Syawkānī, Muḥammad ibn 'Alī. Nayl Al-Awțār. Mesir: Dār al-Ḥadīth, 1993.

Asena Karipek. "Portrayals of Jihad: A Cause of Islamophobia." Islamophobia Studies Journal 5, no. 2 (2020): 210-55. https://doi.org/10.13169/islastudj.5.2.0210.

Asy'arī, Hāsyim. "Jāmi'at Al-Maqāṣid Fī Bayān Mabādi' Al-Tawhīd Wa AlFiqh Wa Al-Tașawwuf Li Al-Murīd." In Irsyād Al-Sārī Fī Jam Mușannafāt Al-Syaykh Hāsyim Asy'arī. Jombang: Al-Maktabah alMasrūrīyah, n.d.

Az-Zuhailī, Wahbah. Al-Fiqh Al-Islāmī Wa Adillatuh. Beirut: Dār al-Fikr, 2007.

Azis Arifin. "Penerapan Metode Ali Mustafa Yaqub Dalam Memahami Hadis Intoleransi Antar Umat Beragama." Jurnal Holistic Al-Hadis 6, no. 1 (2020): 1-25.

Azis, Lasman. "Jihad Perspektif Hadis." Al-Tasyri'iy 2, no. 1 (2019): 1-8.

Azra, Azyumardi. "Islam Indonesia: Kontribusi Pada Peradaban Global." Prisma 29, no. 4 (2010): 83-91. https://www.prismajurnal.com/issues.php?id=54666a8e-56c011e3-a6cc-429e1b0bc2fa\&bid=29ac1eea-56b8-11e3-a6cc$429 \mathrm{e} 1 \mathrm{~b} 0 \mathrm{bc} 2 \mathrm{fa}$.

-_- Islam Nusantara, Jaringan Global Dan Lokal. Jakarta: Mizan, 2002.

Barnes, Paul. "North of 26 South and the Security of Australia, Views from The Strategist." Australian Strategic Policy Institute, 2019, 1-38. https://www.jstor.org/stable/resrep23032.

Brown, Daniel W. Rethinking Tradition Modern Islamic Thought Indeks. Cambridge: Cambridge University Press, 1999.

Bruinessen, Martin van. "Traditionalist and Islamist Pesantrens in 
Contemporary Indonesia." In The Madrasa in Asia. Amsterdam: Amsterdam University Press, 2008.

Choironi, M. Alvin Nur. "Biografi Singkat KH. Ali Mustafa Yaqub." Islami, 2018. http://www.datdut.com/bukan-wahabi/.

Fatihunnada. "Moderate of Islam Indonesia: Political Views of Indonesia Hadith Scholar." In Proceedings of the 1st International Conference on Recent Innovations, edited by Taqwa Hariguna, 1606-1613. Scietpress Digital Library, 2021. https://doi.org/10.5220/0009932616061613.

Fauziyah, Syifa. "Ini 5 Fakta Tak Terbantahkan Kalau Prof. Dr. K.H. Ali Mustafa Yaqub Bukan Wahabi." Datdut, 2016.

Feener, R. Michael. "Indonesian Movements for the Creation of a 'National Madhhab."' BRILL Journal of Islamic Law and Society 9, no. 1 (2002):

83-115.

https://doi.org/https://doi.org/10.1163/156851902753649298.

Foucault, Michel. The Archeology of Knowledge and Discourse on Language. London: Tavistock, 1972.

Handoko, Agus. "Analisis Kejahatan Terorisme Bergedok Agama." Salam 6, no. 21 (2019): https://doi.org/https://doi.org/10.15408/sjsbs.v6i2.11041.

Harris Yonatan Parmahan Sibue. "Upaya Penanggulangan Terorisme Di Indonesia." Isu Sepekan 1, no. 1 (2021). https://berkas.dpr.go.id/puslit/files/isu_sepekan/Isu Sepekan--I-P3DI-April-2021-215.pdf.

Hāsyim Asy'arī. "Risālat Ahl Al-Sunnah Wa Al-Jamā'ah." In Irsyād Al-Sārī Fī Jam' Mușannafāt Al-Syaykh Hāsyim Asy'arī. Jombang: AlMaktabah al-Masrūrīyah, n.d.

Hendrajaya, Jerry, and Amru Almu'tasim. “Tradisi Selamatan Kematian Nyatus Nyewu: Implikasi Nilai Pluralisme Islam Jawa." Jurnal Lektur Keagamaan 17, no. 2 (2019): 431-60. https://doi.org/10.31291/jlk.v17i2.756.

Ibn Mājah, Muḥammad ibn Yazīd. Sunan Ibn Mājah. Kairo: Dār Iḥyā' al- 
Kutub al-'Arabiyyah, n.d.

Ibn Rajab, 'Abd ar-Raḥmān ibn Aḥmad. Fatḥ Al-Bārī Syarḥ Saḥịh AlBuhkārī. Kairo: Maktab Taḥqīq Dār al-Ḥaramain, 1996.

Ibn Taimīyah, Ahmmad ibn 'Abd al-Ḥalīm al-Ḥarranī. Majmú' Al-Fatāwā. Madinah: Majma' al-Malik Fahd, 1995.

Igualada, Carlos, and Javier Yagüe. "The Use of Bay'ah by the Main SalafiJihadist Groups." Perspectives on Terrorism 15, no. 1 (2021): 39-48.

Ilyas, Mohammad Syairozi Dimyathi and Fatihunnada. "The Role of Religious Institutions in Preventing Radical Leftism." In Proceedings of the 2nd International Conference on Islam, Science and Technology (ICONIST 2019), edited by Wadim Striełkowski, 24-28. Atlantis Press, 2020. https://doi.org/https://doi.org/10.2991/assehr.k.200220.005.

IslamLib. "Husein Muhammad Perempuan Boleh Mengimami Laki-Laki." IslamLib, 2005.

Kedar, Mordechai and David Yerushalmi. "Sharia Adherence Mosque Survey: Correlations between Sharia Adherence and Violent Dogma in U.S. Mosques." Perspectives on Terrorism 5, no. 5-6 (2011): 81-138. http://www.terrorismanalysts.com/pt/index.php/pot/article/vi ew/sharia-adherence-mosque-survey.

M., Miski M. "Pemahaman Hadis Ali Mustafa Yaqub Studi Atas Fatwa Pengharaman Serban Dalam Konteks Indonesia." Riwayah 2, no. 1 (2016): 15-31. https://doi.org/10.21043/riwayah.v2i1.1625.

Mahfudhon, Ulin Nuha. Biografi Kyai Ali Mustafa Yaqub, Meniti Dakwah Di Jalan Sunnah. Jakarta: Maktabah Darus-Sunnah, 2018.

Mahsus, Muhammad. "Tafsir Kontekstual Dan Eksistensi Perempuan Serta Implikasinya Terhadap Penyetaraan Bagian Waris Laki-Laki Dan Perempuan." JIL: Journal of Islamic Law 1, no. 1 (2020): 25-44. https://doi.org/10.24260/jil.v1i1.19.

Mangasing, Mansur. "Muhammad Ibn 'Abd Al-Wahhab Dan Gerakan Wahabi.” Jurnal Hunafa 5, no. 3 (2008): 319-28. 
https://doi.org/https://doi.org/10.24239/jsi.v5i3.181.319-328.

Muhaimin, A. G. The Islamic Traditions of Cirebon: Ibadat and Adat Among Javanese Muslims. Canberra: ANU E Press, 2006.

Muhajirin. "Transmisi Hadis Di Nusantara: Peran Ulama Hadis Nusantara Muhammad Maḥfūẓ Al-Tarmasī." UIN Syarif Hidayatullah, 2009.

Muhammad, Husein. Fiqh Perempuan: Refleksi Kiai Atas Wacana Agama Dan Gender. Yogyakarta: LKiS, 2001.

Muhammad Irfan Helmy. Kontekstualisasi Hadis: Telaah Atas Asbab Al-

Wurud Dan Kontribusinya Terhadap Pemahaman Hadis. Yogyakarta: Mitra Cendekia, 2007.

Mujiyo. "Syarah Hadis Dalam Tradisi Keilmuan Islam: Genealogi Dan Metodologi." UIN Syarif Hidayatullah, 2012.

Mustapha, Hamza. The Al-Nusra Front: From Formation to Dissension. Doha: Arab Center for Research and Policy Studies, 2014.

Nengsih, Desri. "Tawassul Dalam Perspektif Hadis (Kajian Terhadap Hadis Kisah Tiga Pemuda Terperangkap Dalam Goa)." Jurnal Ulunnuha 9, no. 1 (2020): 74-92.

Nurani, Herlina dan Ahmad Ali Nurdin. "Pandangan Keagamaan Pelaku Bom Bunuh Diri Di Indonesia." Journal of Islamic Studies and Humanities 3, no. 1 (2018): 79-102. https://doi.org/https://doi.org/10.21580/jish.31.2936.

Nurdin, Nasrullah. "Prof. Dr. KH. Ali Mustafa Yaqub, MA.: Muhaddis Nusantara Bertaraf Internasional." Jurnal Lektur Keagamaan 14, no. 1 (2016): 197-228. https://doi.org/https://doi.org/10.31291/jlk.v14i1.481.

Nz, Adriansyah. "Shifting Paradigm Pemahaman Hadis Di Indonesia (Studi Interpretasi Kontekstual Ali Mustafa Ya'Qub Terhadap Hadis-Hadis Hubungan Dengan Non-Muslim)." Jurnal Ilmu Agama: Mengkaji Doktrin, Pemikiran, Dan Fenomena Agama 20, no. 2 (2019): 203-34. https://doi.org/10.19109/jia.v20i2.5077.

Pratomo, Hilmy. "Transformasi Metode Bahtsul Masail Nu Dalam Berinteraksi Dengan Al-Qur'an." Jurnal Lektur Keagamaan 18, no. 
1 (2020): 109-34. https://doi.org/10.31291/jlk.v18i1.620.

Qomarullah, Muhammad. "Pemahaman Hadis Ali Mustafa Yaqub Dan Kontribusinya Terhadap Pemikiran Hadis Di Indonesia." AL QUDS : Jurnal Studi Alquran Dan Hadis 4, no. 2 (2020): 383. https://doi.org/10.29240/alquds.v4i2.1862.

Ramadhan, M Rizki Syahrul. "Metode Kritik Hadis Ali Mustafa Yaqub; Antara Teori Dan Aplikasi." Nabawi: Journal of Hadith Studies 1, no. 1 (2020): 23-44.

Redaksi. “Ini 5 Alasan Orang Syiah Dan Liberal Tidak Suka K.H. Ali Mustafa Yaqub.” Datdut, 2019.

Ridwan, Nur Khalik. "Tanggapan Atas Tulisan KH Ali Mustafa Yaqub Soal Wahabi-NU." Nu Online, 2015.

Rosenthal, Franz. A History of Muslim Historiography. Leiden: E.J. Brill, 1968.

Sabrina, Laila. “Muhammad Hasbi Siddiqi’ View on Sunnah | فكرة الأستاذ الدكتور .محمّد حسبي الصّديقي عن السنّة النبوية." AL-Zahra : Journal for Islamic and Arabic Studies 13, no. 2 (2016). https://doi.org/10.15408/zr.v13i2.10672.

Saputra, Hasep. "Genealogi Perkembangan Studi Hadis DI Indonesia." $A L$ QUDS : Jurnal Studi Alquran Dan Hadis 1, no. 1 (2017): 41-68. https://doi.org/http://dx.doi.org/10.29240/alquds.v1i1.164.

- - - "Perkembangan Studi Hadis Di Indonesia: Pemetaan Dan Analisis Ganeologi." UIN Syarif Hidayatullah, 2014.

Sarwat, Ahmad. "Wanita Haram Menjadi Imam Buat Laki-Laki." Rumah Fikih Indonesia, 2012. https://rumahfiqih.com/x.php?id=1330332554.

Shelley, Louise I. "Illicit Trade and Terrorism." Perspectives on Terrorism 14, no. 4 (2020): 7-20. https://www.jstor.org/stable/26927661.

Sookhedeo, Patrick. "Issues of Interpreting the Koran and Hadith." The Quarterly Journal 5, no. 3 (2006): 57-83. https://doi.org/http://dx.doi.org/10.11610/Connections.05.3.06. 
Subagyo, P. Ari. "Representasi Frame Dalam Latar Belakang Wacana Tajuk Tentang Terorisme." Litera: Jurnal Penelitian Bahasa, Sastra, Dan Pengajarannya 15, no. 1 (2016): 173-88. https://doi.org/https://doi.org/10.21831/ltr.v15i1.9777.

Suryadilaga, M. Alfatih. "Hadis-Hadis Tentang Perempuan Sebagai Imam Shalat." Musawa 10, no. 1 (2011): 1-32. https://doi.org/https://doi.org/10.14421/musawa.2011.101.132.

Syamsurijal S. “Kontroversi Imam Perempuan: Studi Maudhu'iy Terhadap Hadist-Hadist Imam Perempuan Dalam Shalat." Al-Fikr 2016, no. $20 \quad$ (n.d.): $2 . \quad$ http://journal.uinalauddin.ac.id/index.php/alfikr/article/view/2319.

Taher, Tarmizi. Membendung Radikalisme. Jakarta: CMM Press, 2004.

Tan, Charlene. Islamic Education and Indoctrination:The Case in Indonesia. Islamic Education and Indoctrination: The Case in Indonesia. New York: Routledge, 2012. https://doi.org/10.4324/9780203817766.

Wadud, Amina. Qur'an and Women: Rereading the Sacred Text from a Woman's Perspective. New York: Oxford University Press, 1997.

Wafa, Muhammad Ali. "Benarkah KH Ali Mustafa Yaqub Penganut Paham Wahabi? (1)." Nu Online, 2017.

Watt, Montgomery. Islamic Fondamentalism and Modernity. London: Routledge, 1988.

Yaqub, Ali Mustafa. Aț-Ṭuruq Aș-Ṣaḥịhah Fì Fahm as-Sunnah AlNabawiyah. Jakarta: Maktabah Darus-Sunnah, 2016.

_-_. Cara Benar Memahami Hadis. Jakarta: Pustaka Firdaus, 2016.

- - - Ijtihad, Terorisme, Dan Liberalisme. Jakarta: Pustaka Firdaus, 2015.

——_. Imam Perempuan. Jakarta: Pustaka Firdaus, 2007.

- - - Islam Is Not Only for Muslims. Jakarta: Maktabah Darus Sunnah, 2016.

———. Titik Temu Wahabi-NU. Jakarta: Maktabah Darus-Sunnah, 2016. 